\title{
Impact of Implementing IPSAS on Public Organizations in Lebanon: An Empirical Study
}

\author{
Hasan El-Mousawi ${ }^{1}$ and Amar Sayed-Ahmad ${ }^{2}$ \\ ${ }^{1}$ Associate Professor, Lebanese University \\ ${ }^{2}$ Instructor, Lebanese University
}

\begin{abstract}
Reform in the public sector organizations starts with reforming the accounting information system. The idea of reform boosted the attempts of certain countries to take steps toward developing the accounting systems in their managements in order to improve their efficiency and to cope with the fast political and economic changes in addition to satisfying the public opinion about getting better services. International organizations, including the International Monetary Fund (IMF) have realized the importance of improving the efficiency of the public sector to improve development rates in developing countries and to get international grants and loans. Thus, a unified way to communicate among countries was needed. This study investigates the impact and impediments of implementing International Public Sector Accounting Standards (IPSAS) in Lebanon. The researchers adopted the analytical descriptive approach utilizing an empirical study. A 3:18.

questionnaire was constructed and distributed among a sample of Lebanese certified public accountants. The research yielded some important findings mainly that adopting and implementing IPSAS lead to the advancement in the qualitative characteristics of financial statements in public organizations in Lebanon. It also concluded that there are some obstacles in adopting and implementing IPSAS in public organizations in Lebanon.

${ }^{*}$ Correspondence to Author:

Hasan El-Mousawi

Associate Professor, Lebanese University

How to cite this article:

Hasan El-Mousawi and Amar Sayed-Ahmad. Impact of Implementing IPSAS on Public Organizations in Lebanon: An Empirical Study. Global journal of Economics and Business Administration, 2019,

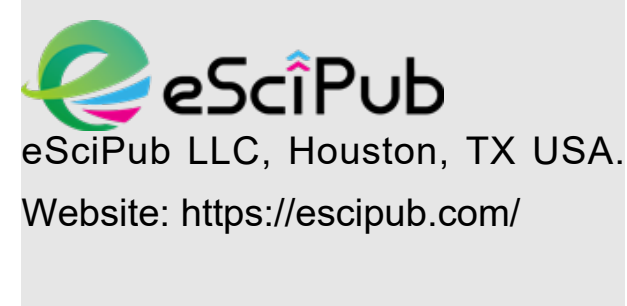

Keywords: public sector, financial statements, financial performance, public organizations, IPSAS 


\section{Introduction}

Public sector accounting may be considered the first of the accounting fields which has been practiced throughout human history. Although this gives it priority in the process of building and developing accounting intellect and setting accounting standards, this is not happening in reality. Instead, the priority was given to another branch, financial accounting. Despite the societies' need for both branches, they diverge when it is related to public service. So many facts and evidence show that public service is affected by public sector accounting more than any other branch of accounting. This suggests that public sector accounting should have been organized and developed before other accounting branches and, consequently, have more attention and consideration.

In accordance with its aim to develop the accounting profession world-wide, the Association of International Accountants (founded in 1928 in the United Kingdom) established the Public Sector Committee (PSC) in 1986, which later became the International Public Sector Accounting Standards Board (IPSASB). This is an independent board that sets accounting standards to be used in the public sector, which were denoted as International Public Sector Accounting Standards (IPSAS) directly supported by the International Federation of Accountants (IFAC) (Deloitte, 2018). The accounting environment in the public sector organizations has distinct characteristics from those in other organizations in the private sector, which impelled the establishment of an independent framework of rules, principles and standards for public sector accounting. For that specific reason, the International Public Sector Accounting Standards Board (IPSASB) developed a set of accounting standards for the public sector in November 2004, which is referred to as the International Public Sector Accounting Standards (IPSAS). Presently, there are 37 active IPSAS's as shown in Table 1 below. This board recognized many essential benefits that could be accomplished using these standards through presenting financial statements conveniently and supplying information about the financial performance of public organizations. This plays an important role in clarifying the requirements of recognition, measurement, presentation and disclosure, which are the most vital accounting principles that enrich accounting information appearing in financial statements.

According to the International Public Sector Accounting Standards Board (IPSASB), the objective of the IPSAS is to set high-quality accounting standards for the public sector and to make adopting and implementing them easy in order to enhance the quality of accounting practice around the world and to improve transparency and accountability of finances in the public sector. These can be used by public sector organizations including national, regional, and local governments. In addition, IPSAS helps in comparability among different periods in different countries (IPSASB, July 2015).

\section{Literature Review}

Over time, countries around the world set and defined standards of financial reporting on their own individual selves (ljeoma and Oghoghomeh 2014). Nevertheless, there has been increased cooperation as international trade among countries was enhanced as a result of globalization. Therefore, there was an urgent need for conformity in standards which set the framework for financial statements so that these statements are understandable to all users wherever they are. For that reason, several governments around the world have adopted and implemented accrual accounting systems. For the past 15 years or so, the Public Sector Committee (PSC) of the International Federation of Accountants (IFAC), which later became the International Public Sector Accounting Standards Board (IPSASB), has developed a set of standards to support such improvements and reforms in public organization accounting. These standards 
came to be known as International Public Olson et al., 2001; Nistor et al., 2009). There Sector Accounting Standards (IPSAS).

In the recent years, there has been a widely recognized tendency related to shifting accounting principles in the public sector organizations from the cash-based to accrualbased accounts which is considered business style (Deaconu et al., 2009; Sutcliffe, 2003; have been many international researches on the public sector accounting which clearly suggest the priority of accrual accounting in providing a clear and transparent image about the financial and non-financial performance of organizations in the public sector (Hodges and Mellette, 2003; Guthrie, 1998).

\section{Table 1: Deloitte, IPSAS in Your Pocket, 2019 Ed.}

\begin{tabular}{|c|c|c|}
\hline IPSAS 1 & Presentation of Financial Statements & IAS 1 \\
\hline IPSAS 2 & Cash Flow Statements & IAS 7 \\
\hline IPSAS 3 & Accounting Policies, Changes in Accounting Estimates and Errors & IAS 8 \\
\hline IPSAS 4 & The Effects of Changes in Foreign Exchange Rates & IAS 21 \\
\hline IPSAS 5 & Borrowing Costs & IAS 23 \\
\hline IPSAS 6 & Consolidated and Separate Financial Statements - superseded by IPSAS 34-38 & IAS 27 \\
\hline IPSAS 7 & Investments in Associates - superseded by IPSAS 34-38 & IAS 28 \\
\hline IPSAS 8 & Interests in Joint Ventures - superseded by IPSAS 34-38 & IAS 31 \\
\hline IPSAS 9 & Revenue from Exchange Transactions & IAS 18 \\
\hline IPSAS10 & Financial Reporting in Hyperinflationary Economies & IAS 29 \\
\hline IPSAS11 & Construction Contracts & IAS 11 \\
\hline IPSAS12 & Inventories & IAS 2 \\
\hline IPSAS 13 & Leases & IAS 17 \\
\hline IPSAS 14 & Events After the Reporting Date & IAS 10 \\
\hline IPSAS 15 & $\begin{array}{l}\text { Financial Instruments: Disclosure and Presentation - superseded by IPSAS } 28 \text { and } \\
\text { IPSAS } 30\end{array}$ & \\
\hline IPSAS 16 & Investment Property & IAS 40 \\
\hline IPSAS 17 & Property, Plant and Equipment & IAS 16 \\
\hline IPSAS 18 & Segment Reporting & IAS 14 \\
\hline IPSAS 19 & Provisions, Contingent Liabilities and Contingent Assets & IAS 37 \\
\hline IPSAS 20 & Related Party Disclosures & IAS 24 \\
\hline IPSAS 21 & Impairment of Non-Cash-Generating Assets & IAS 36 \\
\hline IPSAS 22 & Disclosure of Financial Information About the General Government Sector & $\mathrm{N} / \mathrm{A}$ \\
\hline IPSAS 23 & Revenue from Non-Exchange Transactions (Taxes and Transfers) & $\mathrm{N} / \mathrm{A}$ \\
\hline IPSAS 24 & Presentation of Budget Information in Financial Statements & $\mathrm{N} / \mathrm{A}$ \\
\hline IPSAS 25 & Employee Benefits - superseded by IPSAS 39 & \\
\hline IPSAS 26 & Impairment of Cash-Generating Assets & IAS 36 \\
\hline IPSAS 27 & Agriculture & IAS 41 \\
\hline IPSAS 28 & Financial Instruments: Presentation & IAS 32 \\
\hline IPSAS 29 & Financial Instruments: Recognition and Measurement & IAS 39 \\
\hline IPSAS 30 & Financial Instruments: Disclosures & IFRS 7 \\
\hline IPSAS 31 & Intangible Assets & IAS 38 \\
\hline IPSAS 32 & Service Concession Arrangements: Grantor & IFRIC 12 \\
\hline IPSAS 33 & First-time Adoption of Accrual Basis IPSASs & $\mathrm{N} / \mathrm{A}$ \\
\hline IPSAS 34 & Separate Financial Statements & IAS 27 \\
\hline IPSAS 35 & Consolidated Financial Statements & IFRS 10 \\
\hline IPSAS 36 & Investments in Associates and Joint Ventures & IAS 28 \\
\hline IPSAS 37 & Joint Arrangements & IFRS 11 \\
\hline IPSAS 38 & Disclosure of Interests on Other Entities & IFRS 12 \\
\hline IPSAS 39 & Employee Benefits & IAS 19 \\
\hline IPSAS 40 & Public Sector Combinations & IFRS 3 \\
\hline IPSAS 41 & Financial Instruments & IFRS 9 \\
\hline IPSAS 42 & Social Benefits & $\mathrm{N} / \mathrm{A}$ \\
\hline
\end{tabular}

GJEBA: https://escipub.com/global-journal-of-economics-and-business-administration/ 
Others suggested that accrual accounting increases transparency (Yamamoto, 1999; Van der Hoek, 2005). Also, some researchers pointed out that accrual-based accounting increases responsibility and accountability (Gillibrand and Hilton, 1998; Perrin, 1998). Adoption of IPSAS can considerably advance the worth of financial reporting in the public sector and thus, augment confidence in the public sector's financial reporting. It is projected that this positive result will affect auspiciously the country's image, which therefore enhances the flow of investments into the local economy (Olayinka et al, 2016).

Other researchers concluded that implementing accrual accounting in the public sector can help reflect possessions of the public organizations and subsequent responsibility (Pallot, 2001; Hodges and Mellette, 2003). In addition, one of the most essential features of the New Public Management (NPM) is the set of reforms brought about into the financial information systems; these changes were crucial in improving decision-making and management of public organizations (Guthrie et al. 1999). Introducing accrual accounting into the public sector is the basis of improvement in the financial information systems, mainly at the expense of the cash accounting systems (Lapsley, 1999). Accounting researchers in the public sector have struggled to put accounting changes into theories utilizing various sociological methods (Van Helden, Johnsen, \& Vakkuri, 2008; Goddard, 2010; Jacobs, 2012).

Some international associations, academics, standards setters, policy makers and professional accountants claimed that the arguments for or against implementing public sector accruals are normative and lack pragmatic evidence (Lapsley, Mussari, \&Paulsson, 2009; Jagalla, Becker, \& Weber, 2011). Nevertheless, the prevalent implementation of accrual accounting in the public sector has been principally coupled with ideas of institutionalism (Jacobs, 2012; Modell, 2013).
Many theoretical perceptions have not been able to elucidate accounting changes as related to external variables or environment. This has become central in regulating global accounting practices. The role of external institutions is not clear in the neo-institutional theory (Meyer \& Rowan, 1977; DiMaggio \& Powell, 1983). It appears that there is a gap between what is anticipated from accrual accounting and the achievements made after its adoption at different organizational levels in practice (Guthrie, 1998). In the literature of public sector accrual, there are questions to be answered which include how those organizational players are proceeding public sector accruals reforms in their particular surroundings, the approach and instrumentations they are using and the detailed hindrances they are coming across while implementing accrual accounting (Adhikari \& Nesbakk, 2016). Implementing accrual accounting in the public sector can promote reporting transparency and accountability in this section. It can also help disclose total costs of governmental activities and services (Bastani, Abolhalaj, Jelodar \& Ramezanian, 2012).

Another element affecting the implementation of accrual accounting in public organizations is the adoption cost, that is determining the required funds to implement the process (Ouda, 2004). IPSASs make records of entries which provide information that is useful in detecting chances for future use and abnormalities and enhance confidence in governmental organizations. However, IPSASs do not encourage accountability, neither do they give citizens knowledge on how government organizations use resources (Okundu, 2015).

There exist other challenges facing the implementation of IPSAS (Otunla, 2014). There is a need for training staffs for the required skills and of different levels, which should be coupled with appropriate legislation to meet what is required. Also, new information technology needs to be developed (both hardware and software) to mechanize the 
procedures, not to mention the changes that should be done in the accounting curricula at the universities so that students of accountancy graduate with full knowledge of the new systems.

Some other researchers argue that implementing accrual accounting in the public sector can be disappointing, based on experiences from other countries. One main demerit of IPSAS is the costs, which include costs of developing new accounting policies, costs of valuing in-hand assets, costs of creating new accounting systems, and costs of developing skills which are required for professionals who prepare financial reports and those who use them (Wynne, 2007). Another critical disadvantage for implementing accrual accounting is that the system is made for profit measurement; nevertheless, the purpose of governmental institutions is not making a profit; rather, their purpose is to supply services for citizens.

There are many factors known to have effects on implementing IPSAS including the extent of public administrators' response as related to the culture of the accounting system which they are used to. Another strong factor is the support the government gets from political leaders and from professional and academic parties. One good factor in achieving desired results from implementing IPSAS is the qualifications and eagerness of the staff to apply the required changes and improvements on the existing accounting system, which should be coupled with establishing a serious communication means that coordinates with public organizations which will apply accrual accounting. Nonetheless, there is lack in the literature of the public sector accrual of views of players at the organizational level; chiefly, certified public accountants, finance officials and policymakers, who are essentially concerned with implementing accrual accounting. In this paper, the researchers investigate the impact of implementing accrual accounting in public organizations in Lebanon and the subsequent effects resulting from it, bearing in mind the financial situation and the huge debt which burdens Lebanon.

\section{Research Problem and Hypotheses}

During the twentieth century, there was an urgent need for an accounting system since it is an essential tool in organizing and measuring accounting and trading transactions, after which the information should be reported and presented to relevant parties who make decisions accordingly. This urged researchers to find a proper framework for principles and standards that should be included in the accounting system. As there exists an accounting system for the private sector, it is reasonable to have one for the public sector which deals with everything related to resources, costs, expenditure, etc relative to the nation. The IPSAS's is the proper mechanism to preserve public finances through implementing a set of rules and regulations on preparing balance sheets and presenting financial operations. Economic changes around the world led to setting forth the IPSAS to organize accounting of the public sector. Based on this the researcher has the following questions:

1. Does adopting and implementing IPSAS lead to the advancement in the qualitative characteristics of financial statements in public organizations in Lebanon from the viewpoint of Lebanese certified public accountants?

From this question, three sub-questions arise:

a. Does adopting and implementing IPSAS lead to the advancement in the qualitative characteristics of financial statements in public organizations in Lebanon from the viewpoint of Lebanese certified public accountants as relative to their education?

b. Does adopting and implementing IPSAS lead to the advancement in the qualitative characteristics of financial statements in public organizations in Lebanon from the viewpoint of Lebanese certified public accountants as relative to their major? 
c. Does adopting and implementing IPSAS lead to the advancement in the qualitative characteristics of financial statements in public organizations in Lebanon from the viewpoint of Lebanese certified public accountants as relative to their years of experience?

2. Are there any obstacles in adopting and implementing IPSAS in public organizations in Lebanon from the viewpoint of Lebanese certified public accountants?

From this question, three sub-questions arise:

a. Are there any obstacles in adopting and implementing IPSAS in public organizations in Lebanon from the viewpoint of Lebanese certified public accountants as relative to their education?

b. Are there any obstacles in adopting and implementing IPSAS in public organizations in Lebanon from the viewpoint of Lebanese certified public accountants as relative to their major?

c. Are there any obstacles in adopting and implementing IPSAS in public organizations in Lebanon from the viewpoint of Lebanese certified public accountants as relative to their years of experience?

Based on the questions and previous studies, the researchers have the following hypotheses to discuss and to be accepted or rejected:

$\mathrm{H}_{1}$ There is a significant difference among viewpoints of Lebanese certified public accountants that adopting and implementing IPSAS lead to the advancement in the qualitative characteristics of financial statements in public organizations in Lebanon.

This hypothesis has three sub-hypotheses:

$\mathrm{H}_{1.1}$ There is a significant difference among viewpoints of Lebanese certified public accountants that adopting and implementing IPSAS lead to the advancement in the qualitative characteristics of financial statements in public organizations in Lebanon as relative to their education.
$\mathrm{H}_{1.2}$ There is a significant difference among viewpoints of Lebanese certified public accountants that adopting and implementing IPSAS lead to the advancement in the qualitative characteristics of financial statements in public organizations in Lebanon as relative to their major.

$\mathrm{H}_{1.3}$ There is a significant difference among viewpoints of Lebanese certified public accountants that adopting and implementing IPSAS lead to the advancement in the qualitative characteristics of financial statements in public organizations in Lebanon as relative to their years of experience.

$\mathrm{H}_{2}$ There is a significant difference among viewpoints of Lebanese certified public accountants that there are some obstacles in adopting and implementing IPSAS in public organizations in Lebanon.

This hypothesis has three sub-hypotheses:

$\mathrm{H}_{2.1}$ There is a significant difference among viewpoints of Lebanese certified public accountants that there are some obstacles in adopting and implementing IPSAS in public organizations in Lebanon relative to their education.

$\mathrm{H}_{2.2}$ There is a significant difference among viewpoints of Lebanese certified public accountants that there are some obstacles in adopting and implementing IPSAS in public organizations in Lebanon as relative to their major.

$\mathrm{H}_{2.3}$ There is a significant difference among viewpoints of Lebanese certified public accountants that there are some obstacles in adopting and implementing IPSAS in public organizations in Lebanon as relative to their years of experience.

\section{Procedures and Methods}

\subsection{Population and Sample Selection:}

The population of the study consists of Lebanese certified public accountants (LACPA) in Beirut because they are the qualified party to respond to the items of the questionnaire since they are the most qualified and their job is most GJEBA: https://escipub.com/global-journal-of-economics-and-business-administration/ 
involved in the subject of the research. The study was limited to a random sample of 123 LACPA members.

\subsection{Instrumentation}

Based on the literature review, an informal discussion with university colleagues in accounting and interviews conducted with members of the Lebanese Association of Certified Public Accountants in addition to the researchers' personal experience, the researchers constructed a Likert Style five-point scale questionnaire and asked LACPA members to respond to 13 items divided into two main domains. The first one measures the impact of adoption of IPSAS on the quality characteristics of financial statements. The second domain measures the impediments of adopting IPSAS in the Lebanese public sector.

The scale ranges as shown in table (2) below:

Findings of the current study show that all subscales were reliable, having Cronbach's Alpha as shown in Table 3 below.

Table 2: Five-Point Likert Style

\begin{tabular}{|l|l|l|l|l|l|}
\hline Answer & Always & Often & Neutral & Rarely & Never \\
\hline Degree & 5 & 4 & 3 & 2 & 1 \\
\hline
\end{tabular}

Table 3: Cronbach's Alpha for the two domains

\begin{tabular}{|l|l|l|}
\hline Domains & $\begin{array}{l}\text { No. of } \\
\text { items }\end{array}$ & $\begin{array}{l}\text { Cronbach's } \\
\text { alpha }\end{array}$ \\
\hline Impact of Adoption of IPSAS on the Quality of Financial Statements & 6 & 0.781 \\
\hline Impediments of Adopting IPSAS in the Lebanese Public Sector & 7 & 0.743 \\
\hline All Domains & 13 & 0.782 \\
\hline
\end{tabular}

\section{Descriptive Statistics for the Sample}

Table 4:Descriptive statistics for the sample relative to education

\begin{tabular}{|c|c|c|c|c|c|}
\hline \multicolumn{6}{|c|}{ Education } \\
\hline & & Frequency & Percent & Valid Percent & Cumulative Percent \\
\hline \multirow[t]{4}{*}{ Valid } & $\mathrm{BSc}$ & 49 & 39.8 & 39.8 & 39.8 \\
\hline & MSc & 53 & 43.1 & 43.1 & 82.9 \\
\hline & $\mathrm{PhD}$ & 21 & 17.1 & 17.1 & 100.0 \\
\hline & Total & 123 & 100.0 & 100.0 & \\
\hline
\end{tabular}

As can be noted from the above table (4), the majority of the sample $(82.9 \%)$ have a bachelor or a master's degree. While the minority of the sample members $(17.1 \%)$ have Ph. D's. This may be because most of the members get involved in the profession directly after graduation and don't have enough time to seek higher education. Instead, they try to develop their skills and gain more experience by practice. 
Table 5: Descriptive statistics for the sample relative to major

\begin{tabular}{|l|l|l|l|l|l|}
\hline \multicolumn{2}{|l|}{ Major } & Frequency & Percent & Valid Percent & $\begin{array}{l}\text { Cumulative } \\
\text { Percent }\end{array}$ \\
\hline \multirow{3}{*}{ Valid } & Accounting & 71 & & & 57.7 \\
\cline { 2 - 7 } & Economics & 8 & 67.7 & 57.7 & 64.2 \\
\cline { 2 - 7 } & Business administration & 36 & 29.3 & 29.3 & 93.5 \\
\cline { 2 - 7 } & Banking and Finance & 8 & 6.5 & 6.5 & 100.0 \\
\cline { 2 - 7 } & Total & 123 & 100.0 & 100.0 & \\
\hline
\end{tabular}

Table 6: Descriptive statistics for the sample relative to years of experience

\begin{tabular}{|l|l|l|l|l|l|}
\hline \multicolumn{2}{|l|}{ Years of experience } & Frequency & Percent & Valid Percent & Cumulative Percent \\
\hline \multirow{4}{*}{ Valid } & $0-5$ years & 12 & 9.8 & 9.8 & 9.8 \\
\cline { 2 - 7 } & $5-10$ years & 27 & 22.0 & 22.0 & 31.7 \\
\cline { 2 - 7 } & $10-15$ years & 65 & 52.8 & 52.8 & 84.6 \\
\cline { 2 - 7 } & 15 years and Above & 19 & 15.4 & 15.4 & 100.0 \\
\cline { 2 - 7 } & Total & 123 & 100.0 & 100.0 & \\
\hline
\end{tabular}

It is evident from the above tables ( 5 and 6 ) that the larger number of respondents (87\%) are majored in Accounting or in Business administration, both of which are closely related to the topic of the research at hand. In addition, it is noted that most of the sample members $(68.2 \%)$ have a experience of 10 or more years in practicing the profession. All of this certify that the sample's responses' are very reliable since they are the most qualified to give clear and accurate responses to the questionnaire items since the topic of the research falls in the heart of their work.

\section{Descriptive Statistics for the mean response} First Domain: Impact of Adoption of IPSAS on the Quality of Financial Statements

Table 7: Mean and standard deviation for the first domain

\begin{tabular}{|l|l|l|l|}
\hline Questions & Mean & Std. Deviation \\
\hline Q1 & $\begin{array}{l}\text { Adopting IPSAS enhances full disclosure of financial statements in the public } \\
\text { organizations. }\end{array}$ & 4.8 & 0.68 \\
\hline Q2 & Adopting IPSAS enhances reliability of financial reporting in public organizations. & 4.65 & 0.64 \\
\hline Q3 & $\begin{array}{l}\text { Adopting IPSAS shows the true image of the financial performance in the public } \\
\text { organizations. }\end{array}$ & 4.29 & 0.64 \\
\hline Q4 & $\begin{array}{l}\text { Adopting IPSAS shows the true image of the statement of financial position in the } \\
\text { public organizations. }\end{array}$ & 4.36 & 0.65 \\
\hline Q5 & $\begin{array}{l}\text { Adopting IPSAS enables comparability of financial statements in various } \\
\text { countries. }\end{array}$ & 4.15 & 1.01 \\
\hline Q6 & $\begin{array}{l}\text { Adopting IPSAS ensures relevance of financial statements in the public } \\
\text { organizations. }\end{array}$ & 4.68 & 0.66 \\
\hline
\end{tabular}


The mean for adopting IPSAS enhances full disclosure of financial statements in the public organizations is high (4.8) and the standard deviation is 0.68 . The reason for this might be that implementing IPSAS requires full disclosure of financial statements which boosts transparency. That is why the IPSASB has specified many paragraphs about disclosure related to the topic in each standard. The mean for adopting IPSAS enhances reliability of financial reporting in public organizations is high (4.65) and the standard deviation is 0.64 . The conceptual framework of IPSAS qualitative characteristics of accounting information regarding the basis of recognition, measurement and disclosure should be internationally unified, financial statements will be more reliable. The mean for adopting IPSAS shows the true image of the financial performance in the public organizations is high (4.29) and the standard deviation is 0.64 , and the mean for adopting IPSAS shows the true image of the statement of financial position in the public organizations is high (4.36) and the standard deviation is 0.65 . Since full disclosure of financial statement is a requirement for IPSAS, financial statement will surely show the true image of the financial performance and of the statement of financial position in the public organizations. The mean for adopting IPSAS enables comparability of financial statements in various countries is high (4.15) and the standard deviation is 1.01 . This is because IPSAS is unified all over the world so it will be easy to compare financial statement among countries which implement IPSAS. The mean for adopting IPSAS ensures relevance of financial statements in the public organizations is high (4.68) and the standard deviation is 0.66 . This is because IPSAS requires full disclosure of financial statements, which enhances transparency and reliability of the figures presented. All this facilitates taking proper decisions.

Second Domain: Impediments of Adopting IPSAS in the Lebanese Public Sector

Table 8: Mean and standard deviation for the second domain

\begin{tabular}{|l|l|l|l|}
\hline \multicolumn{2}{|l|}{ Questions } & Mean & Std. Deviation \\
\hline Q7 & Adopting and implementing IPSAS is very costly. & 3.93 & 1.01 \\
\hline Q8 & Adopting and implementing IPSAS lacks necessary legislation. & 4.22 & 0.61 \\
\hline Q9 & $\begin{array}{l}\text { The lack of trained and competent accounting personnel is a } \\
\text { hindrance to adopting IPSAS. }\end{array}$ & 4.62 & 0.59 \\
\hline Q10 & There is lack of appropriate technology for implementing IPSAS. & 3.71 & 0.93 \\
\hline Q11 & Some politicians are against adopting and implementing IPSAS. & 2.74 & 0.84 \\
\hline Q12 & $\begin{array}{l}\text { The current accounting system in the Lebanese public sector depends } \\
\text { on inaccurate financial statements, which is incompatible with IPSAS. }\end{array}$ & 3.98 & 0.87 \\
\hline Q13 & $\begin{array}{l}\text { Absence of international donors to support implementing IPSAS is a } \\
\text { hindrance. }\end{array}$ & 2.92 & 0.96 \\
\hline
\end{tabular}

The mean for adopting and implementing IPSAS is very costly is high (3.93) and the standard deviation is 1.01 . The reason behind this might be that implementing IPSAS requires having a lot of computers and relevant accessories and the like. Moreover, it requires training for personnel to operate this new technology keeping in mind the deteriorating 
financial situation in Lebanon at present. The researchers believe that implementing IPSAS might be costly; however, the outcome is worth it. The mean for adopting and implementing IPSAS lacks necessary legislation is also high (4.22) and the standard deviation is 0.61 . The first step in implementing IPSAS is legislation, and, at present, the parliament has not issued any related legislation which impels application of IPSAS. The mean for lack of trained and competent accounting personnel is a hindrance to adopting IPSAS is high (4.62) and the standard deviation is 0.59 . The accounting personnel is not qualified for working in accordance to IPSAS which requires specific knowledge in computers and some related software. In addition, IPSAS was recently introduced in higher education curriculum (Master's Degree) and most of the public sector employees have been assigned in their work long before introducing IPSAS; thus, they don't have the required knowledge or skill to work accordingly. The mean for there is lack of appropriate technology for implementing IPSAS is 3.71 and the standard deviation is 0.93 . The reason behind this might be that some public organizations in Lebanon have just recently began using technology in some parts of their work; thus, this technology is primitive and needs to be upgraded to be compatible with IPSAS. The mean for some politicians are against adopting and implementing IPSAS is 2.74, which is relatively low, and the standard deviation is 0.84 . The reason behind this may be that a good number of politicians are going for reforms and are trying to battle against corruption in the current situation in Lebanon. The mean for the current accounting system in the Lebanese public sector depends on inaccurate financial statements, which is incompatible with IPSAS is high (3.98), and the standard deviation is 0.87 . This might be because the current Lebanese accounting system adopts a modified system which is a mix between cash and accrual bases. However, financial statements in the Lebanese public organizations lack full disclosure and transparency. The mean for absence of international donors to support implementing IPSAS is a hindrance is 2.92 and the standard deviation is 0.96 . The researchers believe that since the mean is not high, the sample does not convey an accurate response, knowing that international donations are not restricted to cash. International donors might help by sending technical assistance which might help accelerate implementing IPSAS.

\section{Testing and Discussing Hypotheses:}

T-Test:

\section{Table 9: Independent T-Test relative to education}

Independent Samples Test

\begin{tabular}{|c|c|c|c|c|c|c|}
\hline Domain & $\begin{array}{l}\text { Education(Undergraduate } \\
\text { and } \quad \text { Postgraduate } \\
\text { degrees) }\end{array}$ & $N$ & Mean & $\begin{array}{l}\text { Std. } \\
\text { Deviation }\end{array}$ & $\begin{array}{l}\text { Sig. }(2- \\
\text { tailed) }\end{array}$ & $\begin{array}{l}\text { at the } 5 \% \\
\text { significance level }\end{array}$ \\
\hline \multirow{2}{*}{$\begin{array}{l}\text { Impact of Adopting } \\
\text { IPSAS }\end{array}$} & Undergraduate(BSc) & 49 & 4.25 & 0.64 & \multirow{2}{*}{0.000} & \multirow{2}{*}{ significant difference } \\
\hline & Postgraduate(MSc, PhD) & 74 & 4.64 & 0.29 & & \\
\hline \multirow{2}{*}{$\begin{array}{l}\text { Impediments of } \\
\text { Adopting IPSAS }\end{array}$} & Undergraduate(BSc) & 49 & 3.75 & 0.81 & \multirow{2}{*}{0.793} & \multirow{2}{*}{$\begin{array}{l}\text { No significant } \\
\text { difference }\end{array}$} \\
\hline & Postgraduate(MSc, PhD) & 74 & 3.72 & 0.19 & & \\
\hline
\end{tabular}


Table 10: Independent T-Test relative to major

\begin{tabular}{|c|c|c|c|c|c|c|}
\hline \multicolumn{7}{|c|}{ Independent Samples Test } \\
\hline Domain & $\begin{array}{l}\text { Major (Accounting and } \\
\text { Non-Accounting) }\end{array}$ & $\mathrm{N}$ & Mean & $\begin{array}{l}\text { Std. } \\
\text { Deviation }\end{array}$ & $\begin{array}{l}\text { Sig. (2- } \\
\text { tailed) }\end{array}$ & $\begin{array}{l}\text { at the } 5 \% \\
\text { significance level }\end{array}$ \\
\hline \multirow{2}{*}{$\begin{array}{l}\text { Impact of Adopting } \\
\text { IPSAS }\end{array}$} & Accounting & 71 & 4.56 & 0.32 & \multirow{2}{*}{0.077} & \multirow{2}{*}{$\begin{array}{l}\text { No significant } \\
\text { difference }\end{array}$} \\
\hline & Non-Accounting & 52 & 4.38 & 0.67 & & \\
\hline \multirow{2}{*}{$\begin{array}{l}\text { Impediments of } \\
\text { Adopting IPSAS }\end{array}$} & Accounting & 71 & 3.87 & 0.59 & \multirow{2}{*}{0.000} & \multirow{2}{*}{$\begin{array}{l}\text { significant } \\
\text { difference }\end{array}$} \\
\hline & Non-Accounting & 52 & 3.54 & 0.37 & & \\
\hline
\end{tabular}

Table 11: Independent T-Test relative to years of experience

\begin{tabular}{|c|c|c|c|c|c|c|}
\hline \multicolumn{7}{|l|}{ Independent Samples Test } \\
\hline Domain & $\begin{array}{l}\text { Years of Experience }(0-10 \\
\text { years, } 10 \text { years and } \\
\text { Above) }\end{array}$ & $\mathrm{N}$ & Mean & $\begin{array}{l}\text { Std. } \\
\text { Deviation }\end{array}$ & $\begin{array}{l}\text { Sig. }(2- \\
\text { tailed) }\end{array}$ & $\begin{array}{l}\text { at the } 5 \% \\
\text { significance } \\
\text { level }\end{array}$ \\
\hline \multirow{2}{*}{ Impact of Adopting IPSAS } & $0-10$ years & 39 & 4.26 & 0.71 & \multirow{2}{*}{0.007} & \multirow{2}{*}{$\begin{array}{l}\text { significant } \\
\text { difference }\end{array}$} \\
\hline & 10 years and Above & 84 & 4.60 & 0.32 & & \\
\hline \multirow{2}{*}{$\begin{array}{l}\text { Impediments of Adopting } \\
\text { IPSAS }\end{array}$} & $0-10$ years & 39 & 3.53 & 0.43 & \multirow{2}{*}{0.002} & \multirow{2}{*}{$\begin{array}{l}\text { significant } \\
\text { difference }\end{array}$} \\
\hline & 10 years and Above & 84 & 3.82 & 0.55 & & \\
\hline
\end{tabular}

From the above three tables, the mean of the undergraduates' responses for the first domainis 4.25 and the standard deviation is 0.64 , while the mean of the postgraduates' responses for the first domain is 4.64 and the standard deviation is 0.29 . It is evident that the mean of postgraduates is higher than that of undergraduates and the significance is less than 0.05; therefore, the first sub-hypothesis which states "There is a significant difference among viewpoints of Lebanese certified public accountants that adopting and implementing IPSAS lead to the advancement in the qualitative characteristics of financial statements in public organizations in Lebanon as relative to their education" is accepted. The mean of the accounting majors' responses for the first domain is 4.56 and the standard deviation is 0.32 , while the mean of the nonaccounting majors responses for the first domain is 4.38 and the standard deviation is 0.67. It is evident that the mean of accounting majors is higher than that of non-accounting majors and the significance is greater than 0.05 ; therefore, the second sub-hypothesis which states "There is a significant difference among viewpoints of Lebanese certified public accountants that adopting and implementing IPSAS lead to the advancement in the qualitative characteristics of financial statements in public organizations in Lebanon as relative to their major" is rejected. The mean of the responses of the sample who have less that 10 years of experience for the first domain is 4.26 and the standard deviation is 0.71 , while the mean of the responses of the sample who have more than 10 years of experience for the first domain is 4.60 and the standard deviation is 0.32 . It is evident that the mean of the responses of the sample who have more than 10 years of experience is higher than that of the responses of the sample who have less that 10 years of experience and the significance is less than 0.05 ; therefore, the first sub-hypothesis which states "There is a significant difference among viewpoints of Lebanese certified public 
accountants that adopting and implementing IPSAS lead to the advancement in the qualitative characteristics of financial statements in public organizations in Lebanon as relative to their years of experience" is accepted.

The mean of the undergraduates' responses for the second domain is 3.75 and the standard deviation is 0.81 , while the mean of the postgraduates' responses for the second domain is 3.72 and the standard deviation is 0.19 . It is evident that the mean of undergraduates is higher than that of postgraduates and the significance is greater than 0.05 ; therefore, the first sub-hypothesis of the second hypothesis which states "There is a significant difference among viewpoints of Lebanese certified public accountants that there are some obstacles in adopting and implementing IPSAS in public organizations in Lebanon relative to their education" is rejected. The mean of the accounting majors' responses for the second domain is 3.87 and the standard deviation is 0.59 , while the mean of the nonaccounting majors responses for the second domain is 3.54 and the standard deviation is 0.37 . It is evident that the mean of accounting majors is higher than that of non-accounting majors and the significance is less than 0.05 ; therefore, the second sub-hypothesis which states "There is a significant difference among viewpoints of Lebanese certified public accountants that there are some obstacles in adopting and implementing IPSAS in public organizations in Lebanon as relative to their major" is accepted. The mean of the responses of the sample who have less that 10 years of experience for the second domain is 3.53 and the standard deviation is 0.43 , while the mean of the responses of the sample who have more than 10 years of experience for the second domain is 3.82 and the standard deviation is 0.55. It is evident that the mean of the responses of the sample who have more than 10 years of experience is higher than that of the responses of the sample who have less that 10 years of experience and the significance is less than 0.05; therefore, the first sub-hypothesis which states "There is a significant difference among viewpoints of Lebanese certified public accountants that there are some obstacles in adopting and implementing IPSAS in public organizations in Lebanon as relative to their years of experience" is accepted.

\section{Conclusions and Recommendations}

The researchers reached some important results. Adopting and implementing IPSAS lead to the advancement in the qualitative characteristics of financial statements in public organizations in Lebanon. This is because it enhances full disclosure of financial statements in the public organizations, shows the true image of the financial performance and statement of financial position in the public organizations, enhances reliability of financial reporting in public organizations, enables comparability of financial statements in various countries and ensures relevance of financial statements in the public organizations. However, there was a significant difference among viewpoints of Lebanese certified public accountants that adopting and implementing IPSAS lead to the advancement in the qualitative characteristics of financial statements in public organizations in Lebanon as relative to their education. Also, there is a significant difference among viewpoints of Lebanese certified public accountants that adopting and implementing IPSAS lead to the advancement in the qualitative characteristics of financial statements in public organizations in Lebanon as relative to their years of experience. Nevertheless, There was no significant difference among viewpoints of Lebanese certified public accountants that adopting and implementing IPSAS lead to the advancement in the qualitative characteristics of financial statements in public organizations in Lebanon as relative to their major. Moreover, the researchers concluded that there are some obstacles in adopting and implementing IPSAS in public organizations in Lebanon. These 
include lack of necessary legislation, lack of trained and competent accounting personnel, lack of appropriate technology and absence of international donors. In addition, the current accounting system in the Lebanese public sector depends on inaccurate financial statements, which is incompatible with IPSAS.

As such, the researchers have the following recommendations:

- Setting appropriate legislation to enforce implementation of IPSAS in the Lebanese public sector is a key factor.

- Workshops and effective training for personnel is essential in implementing IPSAS in the Lebanese public sector.

- Developing the curriculum in universities so that undergraduates may learn about IPSAS before engaging in their profession.

- Acquiring proper and modern technology is vital in implementing IPSAS in the Lebanese public sector.

- Spreading awareness about the importance of implementing IPSAS in the Lebanese public sector is fundamental.

- Modifying the current accounting system in the Lebanese public sector helps implement IPSAS.

\section{References}

1. Adhikari, P., \& Nesbakk, L., (2016). Implementing Public Sector Accruals in OECD Member States: Major Issues and Challenges, Accounting Forum, Vol. 40, no. 2, pp: 125-142.

2. Bastani, P., Abolhalaj, M., Jelodar, H.M., \& Ramezanian, M. (2012). Role of Accrual Accounting in Report Transparency and Accountability Promotion in Iranian Public Health Sector, Middle-East Journal of Scientific Research, Vol. 12 no. 8 pp: 1097-1101.

3. Deaconu, A., Nistor, C.S. and Filip, C.I., (2009). The Effect of Transiting from Cash Accounting to Accrual Accounting on Performance in the Public Sector, Studia Universitatis Babeş-Bolyai Oeconomica, Vol. 54, pp. 115-129.

4. Deloite, (2019). IPSAS in Your Pocket. Available for download at https://www.iasplus.com/en/publications/publicsector/ipsas-in-your-pocket-2019 [Accessed on Mar. 15 $\left.{ }^{\text {th }}, 2019\right]$.
5. DiMaggio, P. J., \& Powell, W. W., (1983). The Iron Cage Revisited: Institutional Isomorphism and Collective Rationality in Organizational Fields, American Sociological Review, Vol. 48 no. 2, pp: 147- 160.

6. Gillibrand, A. and Hilton, B., (1998). Resource Accounting and Budgeting: Principles, Concepts and Practice - The MoD Case, Public Money and Management, Vol. 18, no. 2, pp. 21-28.

7. Goddard, A., (2010). Contemporary Public Sector Accounting Research-An International Comparison of Journal Papers, The British Accounting Review, Vol. 42 no. 2, pp: 75-87.

8. Guthrie, J., (1998). Application of Accrual Accounting in the Australian Public Sector Rhetoric or Reality?, Financial Accountability and Management, Vol. 14, no. 1, pp. 1-19.

9. Guthrie, J., Olson, O. and Humphrey, C., (1999). Debating Developments in New Public Financial Management: The Limits of Global Theorizing and Some New Ways Forward, Financial Accountability \& Management, Vol. 15, no. 3-4, pp. 209-228.

10. Hodges, R. and Mellett, H., (2003). Reporting Public Sector Financial Results, Public Management Review, vol. 5, no. 1, pp: 99-113.

11. ljeoma, N.B. \& Oghoghomeh, T., (2014). Adoption of International Public Sector Accounting Standards in Nigeria: Expectations, Benefits and Challenges. Journal of Investment and Management, Vol.3, no. 1, pp: 21-29.

12. IPSASB, July 2105. Exposure Draft 56: The Applicability of IPSASs. IFAC Publications. Available at https://www.ifac.org/system/files/publications/files /IPSASB-Exposure-Draft-56-The-Applicability-ofIPSASs.pdf [Accessed Apr. 20 $0^{\text {th }}$, 2019].

13. Jacobs, K., (2012). Making Sense of Social Practice: Theoretical Pluralism in Public Sector Accounting Research, Financial Accountability \& Management, Vol. 28 no. 1, pp: 1-25.

14. Jagalla, T., Becker, S., \& Weber, J., (2011). A Taxonomy of the Perceived Benefits of Accrual Accounting and Budgeting: Evidence from German States, Financial Accountability \& Management, Vol. 27, no. 2, pp: 134-165.

15. Lapsley, I., (1999). Accounting and the New Public Management: Instruments of Substantive Efficiency or a Rationalizing Modernity?, Financial Accountability Management, Vol. 15, no. 3, pp. 201-207.

16. Lapsley, I., Mussari, R., \& Paulsson, G., (2009). On the Adoption of Accrual Accounting in the Public Sector: A Self-Evident and Problematic Reform, European Accounting Review, Vol. 18 no. 4, pp: 719-723. 
17. Meyer, J., \& Rowan, B., (1977). Institutional Organizations: Formal Structures As Myth and Ceremony, American Journal of Sociology, Vol. 83 no. 2, pp: 340-363.

18. Nistor, C.S., Deaconu, A. and Cirstea, A., (2010). Study Concerning the Level of Closeness between the Romanian Public Accounting System and IPSAS Referential, International Journal of Business Research, Vol. 10, pp. 155178.

19. Nistor, C.S., Deaconu, A. and Severin, A., (2009). Stability and Coherence in Transition, a Wish That Can Be Accomplished? The Accounting System of Romanian Public Institutions, Journal of International Business and Economics, Vol. 9, no. 2, pp. 106-124.

20. Okungu, T. O., (2015). The Impact of Implementation of International Public Sector Accounting Standards on Financial Reporting in Public Sector in Kenya, University of Nairobi Research

Archive, http://hdl.handle.net/11295/94470 [Accessed Apr. 12 $\left.{ }^{\text {th }}, 2019\right]$.

21. Olayinka, E; Okoye, L. U; Nwannwka J. M.; and Olaoye, O., (2016). International Public Sector Accounting Standards (IPSAS) Adoption and Quality of Financial Reporting in the Nigerian Public Sector. ESUT Journal of Accountancy, Vol. 7, no. 2, pp: 22-30

22. Olson, O., Humphrey, C. and Guthrie, J., (2001). Caught in an Evaluatory Trap: A Dilemma for Public Services under NPFM.European Accounting Review, Vol. 10, no. 3, pp. 505-522.

23. Otunla, J.O. (2014), The Implementation of The International Public Sector Accounting Standards In Nigeria: The Journey so Far. A Presentation at the Annual Accountants' Conference of ICAN.

24. Ouda, H., (2004) Basic Requirements Model For Successful Implementation Of Accrual Accounting In The Public Sector, Public Fund Digest, Vol. 4, No. 1 pp: 78-99.

25. Pallot, J., (2001). A Decade in Review: New Zealand's Experience with Resource Accounting and Budgeting, Financial Accountability and Management, Vol. 17, no. 4, pp. 383-400.

26. Perrin, J., (1998). Resource Accounting and Budgeting: From Cash to Accruals in 25 Years, Public Money and Management, Vol. 18, no. 2, pp. 7-10.

27. Sutcliffe, P., (2003). The Standards Programme of IFAC's Public Sector Committee, Public Money and Management, Vol. 23, no. 1, pp. 2936.

28. Van der Hoek, M.P.,(2005). From Cash to Accrual Budgeting and Accounting in the Public
Sector: The Dutch Experience, Public Budgeting and Finance, Vol. 25, no. 1, pp. 32-45.

29. Van Helden, J., Johnsen, A., \& Vakkuri, J., (2008). Distinctive Research Patterns on Public Sector Management Accounting Research, Financial Accountability \& Management, Vol. 26 no. 2, pp: 213-240.

30. Wynne, A. 2007. Is the Move to Accrual Based Accounting a Real Priority for Public Sector Accounting. Public Fund Digest, Vol. 6, No. 1 (Available at https://ssrn.com/abstract=1320219) [Accessed Apr. 18 ${ }^{\text {th }}, 2019$ ].

31. Yamamoto, K., (1999). Accounting System Reform in Japanese Local Governments, Financial Accountability and Management, Vol. 15, no. 3-4, pp. 291-307.

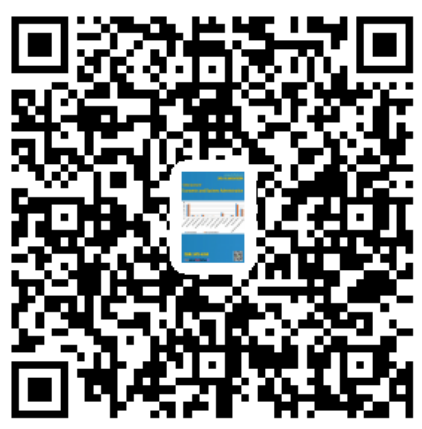

